\title{
Editorial: Lifetime values and valuing customers - Who are you kidding?
}

Over the last couple of years, much has been written about customer relationship management (CRM), customer lifetime values and why we should calculate them. Loyalty cards have popped up here, there and everywhere, with papers on loyalty and lifetime values in learned journals, not to mention countless conferences, seminars and workshop sessions all focusing on what loyal customers are worth.

Although analysis of lifetime values is most familiar in the context of big customer databases, a couple of visits to my local supermarket helped me put some of this work in context.

Over six-packs of own-brand apple juice was a notice in red proclaiming 'One Free', and the endorsement ' 6 for the price of 5'. The latter was sort of true, but only if you bought five individual one litre packs rather than a four pack plus one. A small point you may think. We all get used to exaggerated claims and like to think we see beyond them. The department manager certainly did not accept that the notice was an insult to customers' intelligence. Although the only sense in which there was 'One Free' was by comparison with someone silly enough to buy five single packs, he saw no implication that customers are that stupid. The six-pack was 'excellent value', and the notice brought this to customers' attention.

If you worked it out - and I already had - a litre of apple juice from the four-pack was actually cheaper than a litre from the hyped six-pack. Why was there no notice about this? Was not the 'One Free' sign likely to mislead busy customers as to which pack was better value for money? From what the manager told me, I gather that the promotion was organised centrally, with large deliveries of six-packs pre-planned. Stocks of four-packs were too low for a big promotion. So, to an extent, the misinformation was deliberate: the store had a vested interest in having customers believe that six-packs offered the best value for money. Of course the real specialist in this area is the mobile phones industry with a plethora of tariffs all carefully calculated to confuse customers about what is the cheapest option.

My first observation, therefore, is this. Companies may go enthusiastically into CRM with an explicit focus on developing customer lifetime values, yet still not recognise the true value of customers in any wider moral sense. CRM does not necessarily mean customer-oriented. Indeed policies specifically directed to the development of customer value may co-exist with attitudes and institutional structures that embody contempt for customers and their rights, and an active denial of worthwhile obligations towards them.

As the holder of a loyalty card, I used the supermarket in question regularly and even deposited money with its 'bank'. I like to imagine analysts in the 
background beavering away to work out the lifetime value of customers, loyalty card-holders, and bank account-holders like myself - and helping shape programmes to strengthen customer loyalty. But I cannot help noticing other forces at work in the shop itself.

For several months some yoghurts were alternately either on special offer at a low price or at a higher price under a notice saying 'Guaranteed Low Price'. They are playing with us. And in produce they are playing with peppers too. Single peppers are grossly overpriced, making it cheaper to buy a bag of three - red, green and yellow rather than the mix of colours that a customer actually wants. In value for money terms, buying two peppers has been rendered an irrational act.

A similar scam is the 'BOGOF' Buy One Get One Free - particularly unfair when it relates to perishables like fresh fruit which is not normally frozen. Packs of prawns are sometimes promoted in this way in my local supermarket though the small print says they are unsuitable for home freezing. BOGOFs prevent customers buying just one item at a good price. Pensioners and singles are second-class citizens by virtue of not spending enough in the store to deserve decent treatment. There is nothing illegal or underhand. It is quite blatant. But that does not make it acceptable.

Perhaps the lifetime value assessment says that family shoppers matter more. Or perhaps the model knows that, although a few might mutter about unfairness, it can count on most of us shrugging our shoulders and carrying on shopping. Either way, it is instructive to recognise that an explicit focus on promoting customer 'loyalty' in its CRM sense does not necessarily imply any commitment to serving the customer base equitably. In one sense this is obvious: identifying some customers as more valuable necessarily means others are of lesser value and, ultimately, less worth taking into account. Even where the focus is on strategies for developing the lifetime values of customers of different kinds, and all customers seem to be equal, the reality is that some will be treated as more equal than others.

Another visit to the supermarket widened my concerns. I was looking for cornflakes. (If the store really does not believe that customers are stupid stupid enough to buy more if goods are constantly moved for no reason - it must be targeting hunt-the-thimble enthusiasts.) I searched high and low, eventually finding the errant cereal in an aisle labelled 'pet food'. The manager laughed 'Oh I never take any notice of them'. The same concern for customers explains aisles choked with goods trolleys, the display of mayonnaise in place of any line which is out of stock, and the use of randomly-scattered gondola ends for products that have run out in their proper place. We can only guess why coat hangers are with detergents not household goods, why icing sugar is not with the sugar but with 'baking ingredients', and why loo roll made of recycled paper is not in 'toilet rolls' but in an aisle labelled 'organic'.

Forget manipulative pricing and discrimination against some types of customer. They are not even paying reasonable attention to the needs of target customers. Yet they give us loyalty cards and expect us to deliver the same lifetime value as if we had immaculate service. And there are analysts in the background building models that assume we will.

I would like to say that they are wrong. Assessments of lifetime value seldom take proper account of how customers are treated. This is unfortunate. It is unrealistic to assume 
that customer lifetime values will never be affected by company actions and attitudes. No business can go out of its way to annoy customers and get away totally unscathed. At some point customers will go elsewhere. The key question is when that point is reached.

There are a number of sectors where physical and institutional obstacles to switching are small and customers may change suppliers almost at will. Historically, it has been easier to change suppliers for car insurance than for property insurance, where mortgage providers previously had to consent and charged for the privilege. Customers change cars more often than they move house, bringing car insurance costs onto the agenda more often, and improving the customer's familiarity with the process. In car insurance, therefore, customer service stood a chance of being that bit more important. While this gave customers some ability to leverage the kind of services they wanted, it was effective only in areas where suppliers genuinely competed with each other. Since most motor insurers operated through brokers and offered similar patterns of service, much of the competition was about price - and that in a high-cost context. It took the arrival of companies like Direct Line to transform what the motor insurance industry delivered to the customer in terms of price, efficiency and convenience. The ability to choose a genuinely different service gives customers something that, by itself, CRM never can. So it is not CRM that is the champion of the customer, but real alternatives.

Customers usually choose between a few alternative suppliers, taking one supplier's whole offering, warts and all. In theory, a customer could buy currency and travellers' cheques from different sources; in practice most cannot be bothered. There is a trade-off between effort and getting precisely the service required. In encouraging cross-selling to maximise customer values, CRM offers reduced effort and so may be rather less exposed to the hard edge of customers' preferences than is ideally the case.

I have higher priorities than paying a fair price for two peppers, and have not voted with my feet to anything like the extent I would like! The distance between supermarkets, their role as the 'one-stop shop', and the fact that I shop in the evening all mean that this would require far more effort than is warranted to avoid petty irritations and manipulation. This will change only if I believe that another supermarket is significantly different and likely to be better taking everything together. Until then, it is grin and bear it.

Unfortunately, there are other areas where customers have even less real leverage, and where it is possible for major players with explicit CRM-based strategies nevertheless to manipulate customers to suit themselves without any real risk of mass defection. In such sectors, customers provide something close to their predicted lifetime values even though they are clearly not treated as they would like.

Years ago I joined a building society which opened its door to me on Saturdays when the bank remained stubbornly closed. Building societies were in the ascendant: customers trusted them, and they seemed keen to offer a more flexible range of services. Assessing the lifetime value of recent converts is not easy: customers gained are easily lost. But, at that point, the potential lifetime value of customers for the first time using building societies as the centre of their financial affairs must have been considerable.

Since then, many building societies have not played too fair by their customers. For years, they gave new 
borrowers lower interest rates than existing customers - with repayment penalties to prevent the natural response. During demutualisation, savers were locked in to accounts paying below market rates just to be sure of qualifying for their windfall shares. Next, TESSA account-holders were locked in by withdrawal penalties, while newer ISA accounts paid better rates. Fortunately, the government put a stop to this: it was government changes to tax free saving that set up savers for this 'sting' in the first place. Today's ploy is deliberately marooning customers in defunct accounts that pay derisory interest rates: official naming and shaming is having an effect but is too slow.

Here some customers have voted with their feet. Customer turnover has risen and customers may be less keen to trust their building society/bank when placing new business. But, at the industry level, this is largely 'churning' with losses balanced by gains, provided companies never step too far out of line with competitors. The widespread adoption of CRM techniques has not and is unlikely to change this situation. Though the mutuals, Richard Branson and others may claim to offer genuinely better deals, consumers are increasingly sceptical about claims from financial service providers. Things will change only if large numbers come to believe that someone really is offering a much better deal overall. While 'better deals' fail to attract large numbers, there is little pressure on the big players to clean up their act.

As we have seen, attaching a monetary value to customers cannot ensure that customers are valued properly as individuals and treated with respect, or that communication with them is accurate and honest. In fact lifetime value analysis can sometimes be divisive, leading the interests of some groups to be put above the interests and needs of others. What is more, CRM contains no mechanism able to guarantee even key target customers better or more relevant services in the future. They may well get only what the prevailing commercial and competitive environment requires. And in sectors where inertia is high or there are big barriers to changing supplier, that may not be very much. There, the real name of the game is 'retention' not 'loyalty'.

Clearly then we cannot look to customer lifetime value analysis to show us how to value the customers we serve. For that we must look to our own values and to the evolving values of society at large. And although certain kinds of overt discrimination are increasingly regarded as unacceptable, we need to be continually alert to the possibility that our marketing activities may have potentially divisive side effects. Nor should we rely on CRM to guarantee better services in the future better matched to customers' needs. For that we need explicit goals defined in terms of levels of service and customer satisfaction.

Only if those goals stem from a proper recognition of the true value of our customers as individuals can we count our company truly 'customer-oriented'. Otherwise we are kidding ourselves!

MARK SHAW

Editorial Board

October 2001 